\title{
Human Security in Nepali Perspective
}

\author{
Arun Kumar Singh \\ Deputy Superintendent of APF, Nepal \\ Student Officer, $4^{\text {th }}$ APF Command and Staff Course \\ Email: alpha.nepal@gmail.com
}

\begin{abstract}
The conventional security paradigm was challenged and changed, especially after the end of the Cold War. It becomes more specific towards the human security when the UNDP published the Human Development Report in 1994. Thus scope of Human Security specifically focuses on different area which is related to the freedom and dignity of an individual thus it is people centric concept. Due to the globalization after the end of the cold war, the underdeveloped countries like Nepal, got globalized impact on human security. The Human security even more compromised due to the internal armed conflict and various kinds of natural disaster including the massive earthquake in 2015. There are regional organizations such as SAARC which mainly focus on the arms proliferation rather than promoting the Human Security. The $21^{\text {st }}$ century became more dangerous due to terrorism, poverty, internal conflict, manmade and natural calamities which challenge to the Human Security globally. Nepal is ranked at $4^{\text {th }}$ position by UNDP, Nepal to the vulnerability to climate change, and less coping capacity to disaster due to poor economic conditions which also leads to the insecurity in Human beings. Even there are global challenges to Human Security and threat from all direction, there are few efforts were taken by the International Organization for the promotion of the Human Security. Thus, Human Security can be promoted by putting the People in a center with coordinated efforts of state as well as non-governmental organization especially by the United Nations with the name of means of collective security.
\end{abstract}

Key words: Human security, people centric, freedom and dignity, security, peace and security

\section{Introduction}

Human security represents a powerful, but controversial, attempt by sections of academic and policy community to redefine and broaden the meaning of security. Traditionally, security meant protection of the sovereignty and territorial integrity of states from external military threats. This was the essence of the concept of national security, which dominated security analysis and policy-making during the cold war period. In the 1970s and 1980s, academic study on security, responding to the Middle East oil crisis and the growing awareness of worldwide environmental degradation, began to think of security in broader, non-military terms. Yet the state remained the object of security, or the entity that is to be protected. The concept of human security challenges the state-centric notion of security by focusing on the individual as the main referent object of security.

The concept of human security has expanded the notion of security. The traditional notion of security was one where policy makers were more interested in making policy for their borders to deter external influence and threats. However, due to the changes occurring in the international arena, where states no longer wage war against each other; other emerging issues, threats and challenges have effectively caused states to unite and pool resources together through joint policy frameworks to tackle these challenges that individual states cannot resolve on their own. Briefly the insufficiencies of national security led to the emergence of human security. While the traditional concept of national security, which dominated the Cold War era, was mainly geared towards the security of states and aimed at protecting their sovereignty and territorial integrity from military threats, the advocates of human security demanded that this traditional notion of security be deepened and widened. Furthermore, non-military risk factors such as poverty, disease, and political violence were to be taken into greater account. In the nuclear debate, for example, it has been argued that the stability and wellbeing of communities and nations rests as much on factors associated with human development, economic growth, and democracy as on acquisition of a weapons arsenal (Acharya, 2004).

In defining the concept, it should be noted that as with all concepts, there is no universally accepted definition for the term. Different academic discourses have framed the term differently as a new theory or concept, as a starting point for analysis, a world view, a political agenda, or as a policy framework(Edwards, 2016). Although the definition of human security remains an open question, there is 
consensus among its advocates that there should be a shift of attention from a state-centered security notion to a people-centered approach to security. It is also imperative to stress that human security is a not a replacement for State security. Rather, it seeks to examine every aspect of human life, taking into account the various possible threats at different levels (local, national and regional). Human security entails a global approach linking security, governance, solidarity and development issues. It addresses security in a broad sense that includes all political, economic, social and environmental dangers (Aduloju \& Pratt, 2014).

This concept Human Security became more prominent with the 1994 Human Development Report issued by the United Nations Development Program on Human Security, which was drafted and championed by former Pakistani Finance Minister MahbubulHaq with strong support from economist Amartya Sen. The report defined the scope of human security to include seven areas:

- $\quad$ Economic Security - an assured basic income for individuals, usually from productive and remunerative work, or, in the last resort, from some publicly financed safety net.

- $\quad$ Food Security- ensuring that all people at all times have both physical and economic access to basic food.

- Health Security - guaranteeing a minimum protection from diseases and unhealthy lifestyles.

- Environmental Security- protecting people from the short- and long-term ravages of nature, manmade threats in nature, and deterioration of the natural environment.

- $\quad$ Personal Security - protecting people from physical violence, whether from the state or external states, from violent individuals or sub-state factors, from domestic abuse, and from predatory adults.

- Community Security - protecting people from the loss of traditional relationships and values, and from sectarian and ethnic violence.

- $\quad$ Political Security - ensuring that people live in a society that honors their basic human rights, and ensuring the freedom of individuals and groups from government attempts to exercise control over ideas and information.

Figure 1 : Areas of Human Security

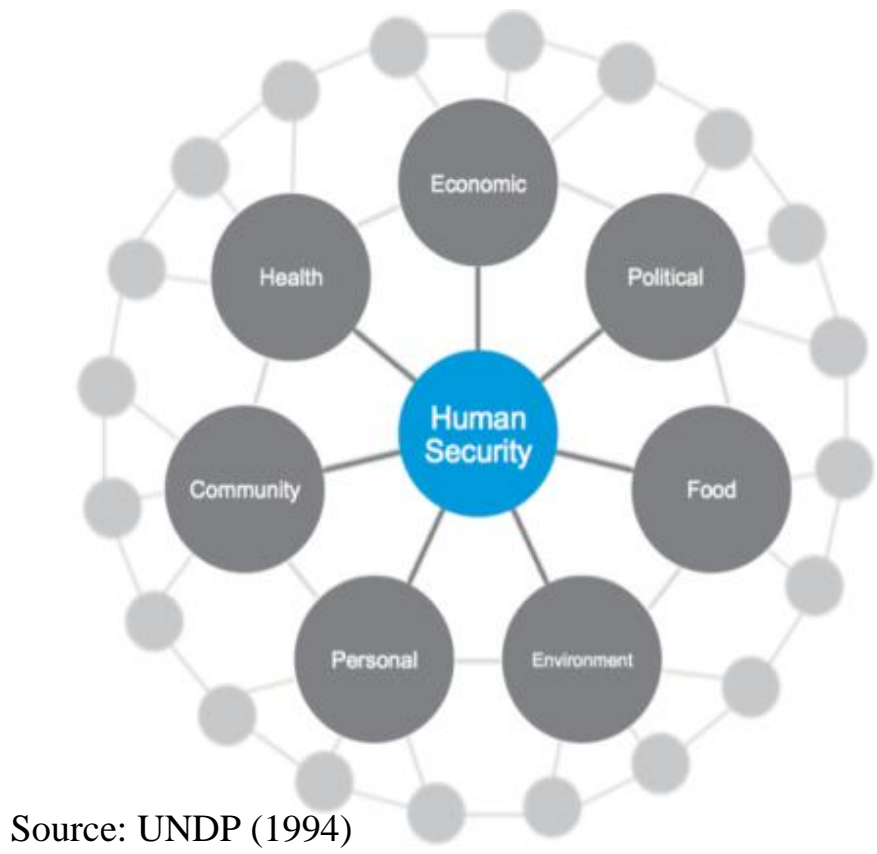

The concept of human security represents both a vertical and a horizontal expansion of the traditional notion of national security such as protection of state sovereignty and territorial integrity from external military threats. In its broader sense, human security is distinguished by three elements, firstly its focus on the individual or people as the referent object of security secondly, its multidimensional nature and lastly, its universal or global scope, applying to states and societies (Baylis, Smith, \& Owens, 2017).

Further, the concept of human security attracted global attention in 1994 when it was discussed in the Annual Human Development Report produced by the United Nations Development Program (UNDP) in 1994. The UNDP report

highlighted the following four core characteristics of human security:

- Human security is a universal concern.

- The components of human security are interdependent.

- Human security is easier to ensure through early prevention than later intervention.

- Human security is people-centered. 


\section{2 | Journal of APF Command and Staff College}

Subsequently, in May 2004, the Human Security Unit was established to manage the UN Trust Fund for Human Security (UNTFHS) and develop practical tools in collaboration with stakeholders to apply human security concepts into practice. The UNTFHS has been financing different projects to promote the agenda of human security and protect vulnerable people across the world (Yousaf, 2017).

\section{Contested Concept of Human Security}

Human security can be said to have two main aspects. It means, first, safety from such chronic threats as hunger, disease and repression. And second, it means protection from sudden and hurtful disruptions in the patterns of daily life-whether in homes, in jobs or in communities. Such threats can exist at all levels of national income and development (UNDP 1994). According to former Pakistani Finance Minister MahbubulHaq, who drafted and championed the Human Development Report in 1994, that Human security is not a concern with weapons. It is a concern with human dignity. Similarly, according to Kofi Annan, Human security can no longer be understood in purely military terms. Rather, it must encompass economic development, social justice, environmental protection, democratization, disarmament, and respect for human rights and the rule of law. Moreover, these pillars are interrelated progress in one area generates progress in another (Baylis et al., 2017). UN Commission on Human Security identified the objective of human security is to safeguard the vital core of all human lives in ways that enhance human freedoms and human fulfillment.

Human security is about security for the people, rather than for states or governments. As such, it has generated much debate. On the one hand, critics wonder whether such an approach would widen the boundaries of security studies too much, and whether 'securitizing' the individual is the best way to address the challenges facing the international community from the forces of globalization. On the other hand, advocates of human security find the concept to be an important step forward in highlighting the dangers to human safety and survival posed by poverty, disease, environmental stress, human rights abuses, as well as armed conflict. However, human security might not just concern human rights and injustices only but it encompasses the environmental security is a massive part of human security as well (Buzan, 2007).

\section{Human Security Paradigm: People Centric}

Human security focus on freedom from fear because firstly, a broad definition is simply an itemized wish list and secondly, there are no clear gains from linking security and development (Krause \& Jütersonke, 2005). The conventional security paradigm was challenged and changed, especially after the end of the Cold War, by rising concerns about who needs to be secured geographical territory or human beings or both. Feeling the need to move beyond military issues or warfare, the scope of the concept of security has been extended to embrace other non-military issues, like health, economy, gender, for the well-being and protection of human beings. Freedom from fear seeks to limit human security to protecting the individual from violence while recognizing that violence is strongly associated with poverty and weak states(Bourne, 2014). The approach of human security places human beings as the main focus of security rather than merely the state. Unlike traditional security framework that relies on building armies and use of force to safeguard territories, the human security emphasizes on development and protection from the perspective of individuals and assumes that all other security concerns derive from the sovereignty of people (MacFarlane \& Khong, 2007). The world is entering a new era in which the very concept of security has been changed dramatically. Security has been interpreted as the Security of people, not just territory; Security of individuals, not just of nations; Security through development, not through arms; Security of all the people everywhere in their homes, in their streets, in their communities, in their environments (Haq, 1995).

The prime concern of those advocating the human security concept is protecting human life and promoting dignity with freedom. The concept of human security is not limited to mere physical survival of people in conditions of war or peace, but is equally concerned with the realization of basic needs of people while protecting their human dignity. Moreover, the approach of human security is protective not reactive, which means it is also cost effective as it prevents threat(s) from occurring or addresses it in the initial stages rather than waiting or delaying the response until the time the threat might become widespread and pose serious risks to humans. Hence, human security requires institutionalized arrangements not only to prevent occurrence of threats but also to foresee any possible threat e.g., famines, floods, and make advance arrangements or have intuitional mechanism in place to minimize the damage caused by sudden disruption of people's everyday lives (Yousaf, 2017). 
A world where the wellbeing of humans will be at the core of all policies, be it social, economic, political, security etc., in order to prevent the outbreak of conflict. It combined the total fulfillment of three fundamental human rights in formulation of the notion of human security:

$$
\begin{aligned}
& \text { - The right to freedom of want } \\
& \text { - } \quad \text { The right to freedom of fear and } \\
& \text { The right of future generations to inherit a healthy planet. }
\end{aligned}
$$

\section{Human Security and the South Asian Association for Regional Cooperation (SAARC)}

The region of South Asia provides an example of stark imbalance between human security and state security as the governments dominantly focus on conventional security, rather than social development, and spend billions of dollars annually on the military-related expenditures, which also makes this region one of the most militarized parts of the world (Karim, 2014). However, on December 8, 1985, seven South Asian states signed the charter to establish the South Asian Association for Regional Cooperation (SAARC) to promote peace and prosperity across the region through mutual collaboration and peaceful settlement of all disputes. However, unlike many other regional organizations (e.g., The European Union), SAARC has had little effect in promoting regional prosperity and well-being of the people through improving the quality of their lives. This is true mainly because conventional issues overshadow nonconventional issues (Yousaf, 2017).

\section{Threats of Human Security}

The United Nations Commission on Human Security defines human security as the effort by states and organizations to protect the vital core of all human lives in ways that enhance human freedoms and human fulfillment as well as empowering people to provide and care for them. Specifically, it entails creating systems that provide people the foundation for survival, dignity and livelihood. This definition encompasses the two core strategies of human security: protection and empowerment of people. In simple terms therefore, this concept emphasizes that in order for people to be secure, their lives must be free from any pervasive threats (violent or benign) to their rights and their safety. It thus encompasses both the traditional and non-traditional threats to people's security. The threat range includes the following:

- Economic threats

- Food threats

- Health threats

- Environmental threats

- Personal threats

- Community threats

- Political threats

- Gender-based threats

- Demographic threats

- Crime in all forms, including terrorism

- Natural disasters

- Violent conflicts and wars

- Genocide

- $\quad$ Anti-personnel mines, Small Arms and Light weapons (Aduloju \& Pratt, 2014) .

\section{Global Challenges of Human Security}

After the first decade of the $21^{\text {st }}$ Century, we have come to recognize that the world has become a dangerous place, with terrorism and bloody local conflicts. Humanitarian efforts and human rights laws are largely ignored and systematically violated. Social inequality, inside states and among states, has increased dramatically, and poverty in the poorest areas is deepening. Consequent increasing competition for scarce resources contributes to unstable political structures and favors eruption of conflicts. Fluctuations in world commodity prices can trigger dangerous destitution and civil strife. Indeed many of the apparently senseless violent conflicts and acts of terrorism in the world become markedly more transparent when such roots are explored. On the basis of different analysis and study, the challenges for the $21^{\text {st }}$ century can be listed as follows: 
64 | Journal of APF Command and Staff College

- Poverty: Gender inequality and poverty are increasing both within and between countries. Humanity possesses both the capital and the knowledge that everyone has enough.

- Hunger and Thirst: Day by day the number of hungry and thirsty people has risen to more than a billion. Enough food stuff is produced every year to feed everyone on earth well, if justly distributed. Increasing production through sustainable agriculture which restores soil and conserves water can ensure that this continues to be the case in coming days as well.

- Climate Change: Due to rapid number of industrialization and deforestation the planet is warming fast, and rising sea levels which caused shifting rainfall that will drive millions of people from their homes, slash harvests, and disrupt societies. Developing existing clean technologies will do much to produce the sustainable growth required to ensure a future of low carbon prosperity.

- Resource Depletion: One of the major problems in the underdeveloped countries that cannot regulate the over-exploiting land, water, fisheries, forests and other natural resources will result in scarcity and growing conflict - and this threatens to get worse as the population rises to nine billion over the next few decades. Just an eighth of global defense spending would provide massively enlarged programs to reduce suffering and the mentioned threats.

- War and Conflict: The world is producing more and more arms and ammunition which needs more spending in this field and which encouraged by deeply entrenched vested interests. There must be a new determination in resolving conflict.

- Reconciliation, justice and forgiveness are interdependent: We must genuinely commit to human rights and International humanitarian law for all and address seriously injustice and oppression (Sommaruga, 2011).

\section{Promoting Human Security}

The role of the international community for the promotion of the human security is very important because of the broad and contested nature of the idea of human security. It is difficult to evaluate policies undertaken by the international community that can be specifically regarded as human security measures (Baylis et al., 2017). But the most important multilateral actions include the establishment of several War Crimes Tribunals, the International Criminal Court (ICC), and the Anti-Personnel Landmines Treaty. It could also be said that Western powers have capitalized on human security and aid, by privatizing companies that provide aid and development agencies to further their own interests(Johns, 2014).

The surge in UN peacekeeping and peacebuilding operations has contributed to the decline in conflict and enhanced prospects for human security. Since 1948, the UN has undertaken 67 peacekeeping operations and over 117,000 personal were serving on the sixteen UN-led peace operations on four continents. UN Specialized Agencies also play a crucial role in promoting human security. For example, the UN Development Program and the World Health Organization (WHO) have been at the forefront of fighting poverty and disease respectively. Other UN agencies, such as the UN High Commissioner for Refugees (UNHCR), the UN Children's Fund (UNICEF), and the UN Development Fund for Women (UNIFEM), have played a central role in getting particular issues, such as refugees and the rights of children and women, onto the agenda for discussion, and in providing a platform for advocacy and action (MacFarlane \& Khong, 2007).

The non-state factors such as non-governmental organizations contribute to human security in a number of ways such as a source of information and early warning about conflicts, providing a channel for relief operations, often being the first to do so in areas of conflict or natural disaster, and supporting government or UN-sponsored peacebuilding and rehabilitation missions. NGOs also play a central role in promoting sustainable development. A leading NGO with a human security mission is the International Committee of the Red Cross (ICRC). Established in Geneva, it has a unique authority based on the international humanitarian law of the Geneva Conventions to protect the lives and dignity of victims of war and internal violence, including the war-wounded, prisoners, refugees, civilians, and other noncombatants, and to provide them with assistance. Other NGOs include Medecins Sans Frontieres (emergency medical assistance), Save the Children (protection of children), and Amnesty (Baylis et al., 2017).

The United Nations is the international organization with mandate of promotes human security in all its facets in the five continents by preserving international stability on the basis of the promotion of values such as: 
- The supremacy of the law

- The respect for democracy

- The defense of human rights

- Equality before the law

- Good public affairs management

- The peaceful resolve of conflicts and

- The protection of the environment, etc.

\section{Human Security in Nepal}

The major human security concerns of Nepal are poverty, social protection, food, health, migration, climate change, environment and politics. As one of the economically very poor nations in the world, Nepal is plagued by poverty and resulting low education and health indicators (Upreti, Bhattarai, \& Wagle, 2013). As a consequence of the poverty, many people living in Nepal experience human insecurity in their daily lives, with little hope of bettering their situation. In this context, Nepal has made improvement towards reducing poverty and its associated development indicators, much more change is required. Only with effective and sustained development efforts will Nepal be able to reverse the insecurity in which many of its people live.

Nepal, as a country very much prone to natural disasters (for example the earthquake in 2015 and other several floods and landslide every year), is in particular need of robust social protection mechanisms for pre-event disaster training and post-event relief packages. While social protection should be a priority of any government, the dual problems of widespread poverty and susceptibility to natural disasters render social protection especially imperative in Nepal (Upreti et al., 2013). In order to counter the geographic, caste and gender dimensions of health security, the Government of Nepal has been trying to introduce systems to improve the health status of marginalized sections of the population; however reforming the country's health system to properly address the existing problems which preclude people from accessing healthcare. The changing domestic and global context, such as increasing dependency on healthcare services as the population ages, mutating and drug-resistant disease strains and bio-terrorism, pose additional threats to Nepal's human security, particularly in health sector.

Nepal is ranked as one of the most climate vulnerable countries in the world (Maplecroft, 2011), making climate change an issue of prime importance to human security. Climate variability impacts human security in many ways; for example, unseasonal weather patterns can adversely affect food and energy production as Nepal is reliant on hydropower. Nepal's strategic location between the rapidly industrializing global powerhouses India and China also impact the status of climate change. Several aspects of environmental security are particularly important in the case of Nepal: its topography, which renders it prone to natural disasters; the need to properly care for agricultural land to ensure food security; the interrelationship between energy production \& consumption pattern; political \& economic instability; and the interrelationship between political tension, conflict and environmental abuse (Upreti et al., 2013). Nepal's topography also plays a part in human security concerns. One consequence of this hugely varied topography is that people residing in the Tarai, Hills and Mountain regions face different human security challenges; for example, inhabitants of the Mountain region often lack easy access to education, healthcare and food reserves. A second human security implication of Nepal's topography is environmental. In a country already prone to heavy monsoonal rains which can result in flooding and landslides, as well as glacial lake outbursts, forest fires and seismic activity, unusual weather patterns have the potential to trigger natural disasters which could result in large-scale displacement, starvation or death. This uncertainty and vulnerability make striving for human security particularly important. Nepal needs to recognize the gravity of this cross-border dimension of human security and begin to work towards addressing it (Stoett, 1999).

Internal problems which cause and/or contribute to human insecurity within Nepal, including poverty, social protection, food, health, migration, climate change, environment and politics, should be of primary concern to Nepal's security agenda. Nepal is actively involved in and often the driving force behind international climate change initiatives, for example at COP 24 in Katowice, Poland. Adopting a human security approach will not only benefit Nepal's inhabitants by improving their human security condition, it will also advance the security of the state. Primarily, a greater sense of public wellbeing would likely result in a more stable political situation. It is especially hoped that the Government of Nepal and its policy-makers start to consider the ideas and implications of human security. 


\section{Conclusion}

The basic concept of human security reflects a number of developments that have incrementally challenged the traditional view of security as the protection of states from military attack. What initially began as a rejection of orthodox notions of economic growth in favor of a broader notion of human development has been reinforced by new security threats such as genocides in the Balkans and Africa, the Asian financial collapse of 1997, and the threat of global pandemics. The concept of human security represents an on-going effort to put the people at the center of national and global security concerns while expanding our understanding of the range of challenges that can threaten individual safety and wellbeing, to encompass both armed conflict and social, economic, and ecological forces. To be sure, human security has travel long journey to have universally accepted definition. The linkages between armed conflict, poverty, disease, and environmental stress are poorly understood and need clarification and elaboration. Nonetheless, there can be little doubt that threats to human security, whether understood as freedom from fear or freedom from want, are real world challenges which cannot be wished away or dismissed because of a lack of agreement over the concept and meaning of human security. Nevertheless debates about the utility and scope of human security, there is increasing acceptance that the traditional notion of security, focusing on state sovereignty, independence, will no longer suffice, and that the international community must develop new responses to ensure the protection of people from transnational dangers in an era of globalization. The challenge for the international community is to find ways of promoting human security as a means of addressing a growing range of complex transnational dangers that have a much more destructive impact on the lives of people than conventional military threats to states. Thus the state as well as non-state factor should focus on the human security for the sustainable development.

\section{References}

Acharya, A. (2004). A holistic paradigm. Security Dialogue, 35(3), 355-356. https://doi.org/10.1177/096701060403500314

Aduloju, A. A., \& Pratt, O. O. (2014). Human security and developmental crisis in the contemporary West Africa. Journal of Human Security, 10(1). https://doi.org/10.12924/johs2014.10010046

Baylis, J., Smith, S., \& Owens, P. (2017). The globalization of world politics: An introduction to international relations (second). Oxford University Press.

Bourne, M. (2014). Understanding security. Houndmills, Basingstoke: Palgrave Macmillan.

Buzan, B. (2007). People, states and fear: An agenda for international security studies in the post-cold war era (2. ed). Colchester: ECPR Press.

Edwards, K. (2016, March 25). Is human security part of the international security agenda? Retrieved December 27, 2018, from https://www.e-ir.info/2016/03/25/is-human-security-part-of-theinternational-security-agenda/

Haq, M. (1995). Reflections on human development. New York: Oxford Univ. Press.

Johns, L. (2014, July 5). A critical evaluation of the concept of human security. Retrieved December 27, 2018, from https://www.e-ir.info/2014/07/05/a-critical-evaluation-of-the-concept-of-human-security/

Karim, M. A. (2014). South Asianregional integration - challenges and prospects. Japanese Journal of Political Science, 15(02), 299-316. https://doi.org/10.1017/S1468109914000085

Krause, K., \& Jütersonke, O. (2005). Peace, security and development in post-conflict environments. Security Dialogue, 36(4), 447-462. https://doi.org/10.1177/0967010605060449

MacFarlane, S. N., \& Khong, Y. F. (2007). United Nations intellectual history project series. 8: human security and the UN: a critical history (Nachdr.). Bloomington, Ind.: Indiana Univ. Press.

Maplecroft, V. (2011). Climate change vulnerability index. Retrieved December 25, 2018, from https://www.maplecroft.com/about/news/ccvi.html

Sommaruga, C. (2011, July 20). The global challenge of human security. Retrieved December 1, 2018, from https://www.diplomaticourier.com/2011/07/20/the-global-challenge-of-human-security/

Stoett, P. (1999). Human and global security: An exploration of terms. Toronto: Univ. of Toronto Press.

UNDP (Ed.). (1994). Human development report 1994. New York: Oxford Univ. Press.

Upreti, B. R., Bhattarai, R., \& Wagle, G. S. (Eds.). (2013). Human security in Nepal: concepts, issues and challenges. Kathmandu: Nepal Institute for Policy Studies and South Asia Regional Coordination Office of NCCR (North -South).

Yousaf, F. N. (2017). Human (in) security in South Asia. South Asian Studies, 32(2), 477-493. 